Jurnal Akuntansi Manajerial

ISSN (E): 2502-6704

Vol. 5, No. 2 Juli - Desember 2020: 1-17
Dipublikasikan oleh Fakultas Ekonomi dan Bisnis

Universitas 17Agustus 1945 Jakarta

http://journal.uta45jakarta.ac.id/index.php/JAM

\title{
Pengaruh Audit Fee Dan Financial Distress Terhadap Auditor Switching Dengan Manajemen Laba Akrual Sebagai Variabel Intervening
}

\author{
Sulaiman Akbar ${ }^{1)}$,Ajeng Wijayanti ${ }^{2)}$ \\ ${ }^{1}$ Mahasiswa Akuntansi, Universitas 17 Agustus 1945 Jakarta \\ Email: Sulaimanakbar0598@gmail.com \\ ${ }^{2}$ Dosen Fakultas Ekonomi dan Bisnis, Universitas 17 Agustus 1945 Jakarta \\ Email: ajeng.wijayanti@uta45jakarta.ac.id
}

\begin{abstract}
Abstrak
Penelitian ini bertujuan untuk menguji pengaruh audit fee dan financial distressterhadap auditor switching dengan manajemenlaba akrual sebagai variabel intervening.Penelitian ini menggunakan data sekunder dengan menggunakan pengumpulan data dokumentasi dan studi pustaka pada situs Bursa Efek Indonesia berupa laporan keuangan tahunan. Populasi yang digunakan dalam penelitian ini adalah perusahaan real estate\& properti yang terdaftar di Bursa Efek Indonesia periode tahun 2014-2018 dengan teknik pengambilan sampel menggunakan purposive sampling method. Hasil dari penelitian ini menunjukan bahwa audit feeberpengaruh terhadap manajemen laba akrual, financial distress tidak berpengaruh terhadap manajemen laba akrual, audit feetidak berpengaruh terhadap auditor switching, financial distresstidak berpengaruh terhadap auditor switching, manajemen laba akrualtidak berpengaruh terhadap auditor switching, dan manajemen laba akrualtidak berhasil memediasi pengaruh audit fee sertafinancial distress terhadap auditor switching.
\end{abstract}

Kata Kunci: Audit Fee, Financial Distress,Auditor Switching, Manajemen LabaAkrual.

\begin{abstract}
The aim of this study is to analyze the influence of Audit Fee, and Financial Ditsress toward Management Change, Auditor Switching,Accrual Earning Management as an intervening variable.This study uses secondary data using documentation data collection and literature study on the Indonesia Stock Exchange website in the form of annual financial reports. The population used in this study were real estate \& property companies listed on the Indonesia Stock Exchange period 2014-2018 with the sampling technique using purposive sampling method. The results of this study indicate that audit fee have an effect on accrual earnings management, financial distress has no effect on accrual earnings management, audit fees have no effect on auditor switching, financial distress has no effect on auditor switching, accrual earnings management has no effect mediation on auditor switching and accrual earnings management. failed to mediate the effect of audit fees and financial distress on auditor switching.
\end{abstract}

Keywords: Audit Fee, Financial Ditsress, Management Change, Auditor Switching,Accrual Earning Management.

\section{PENDAHULUAN}

Di era globalisasi revolusi idustri 4.0 ini semakin pesat perkembangan bisnis, maka dari itu semakin meningkatnya dunia bisnis akan semakin meningkat pula jasa para akuntan. Semakin tinggi nilai perusahaan akan menimbulkan terjadinya fraud terhadap laporan keuangan, oleh karena itu untuk menghindari tingkat kecurangan pemangku kepentingan dan adanya potensi konflik 
kepentingan (conflict of interest) di antara penyedia informasi dan pemakai informasi permintaan ini menimbulkan adanya pihak penengah atau perantara yang dapat memastikan kredibilitas dari informasi tersebut. Diperlukannya jasa akuntan untuk menjadi penengah diantara para pemangku kepentingan juga menyajikan laporan keuangan yang relevan sehingga para pengguna dapat memakainya untuk mengambil keputusan.

Indonesia menjadi salah satu negara yang menerapkan peraturan pergantian auditor secara mandatory (wajib), akan tetapi justru fenomena yang sering terjadi di Indonesia adalah pergantian auditor secara voluntary (sukarela) oleh para perusahaan. Pada awalnya kewajiban rotasi auditor diatur dalam Keputusan Menteri Keuangan Republik Indonesia Nomor 423/KMK.06/2002, kemudian diperbaharui dengan Peraturan Menteri Keuangan (PMK) No.17/PMK.01/2008 tentang Jasa Akuntan Publik dalam pasal 3 ayat (1) dijelaskan bahwa sebuah KAP hanya boleh mengaudit suatu perusahaan paling lama 6 (enam) tahun buku berturut-turut. Pergantian auditor secara sukarela di Indonesia termasuk dalam kategori relatif tinggi, walaupun ini akan menimbulkan risiko bagi perusahaan. Perusahaan yang sering melakukan pergantian akan mengakibatkan biaya audit yang relatif lebih tinggi dan juga di tahun pertama akan sedikit mengganggu kenyamanan kerja karyawan (Widnyani \& RM, 2018).

Merebaknya pandemi covid-19 menyebabkan krisis perekonomian yang mungkin saja jauh lebih besar dibandingkan yang pernah terjadi sebelumnya dan juga dapat meningkatkan prevalensi risiko kesalahan penyajian material pada asersi-asersi manajemen dalam laporan keuangan. Krisis ekonomi akibat pandemi covid-19 ini tidak hanya berdampak bagi negara, profesi, ataupun populasi tertentu saja, tetapi juga berdampak ke semua negara di seluruh penjara dunia dan juga pamdemi covid-19 telah mendorong berbagai pihak mulai menggunakan sistem kerja jarah jauh dan online. Adanya perubahan pola kerja ini ternyata berimplikasi dengan interaksi yang terjadi antara akuntan dengan sutau perusahaan (klien)serta karyawannya dalam proses pelaksanaan audit. Bagi perusahaan yang tidak mengikuti kemajuan teknologi akan kesulitan menghadapi situasi seperti ini, begitupun dengan auditor eksternal yang dibatasi akses dan perjalanan serta terbatasnya ketersediaan personel karena pertimbangan kesehatan sehingga dapat mengganggu kemampuan auditor untuk mendapatkan bukti audit yang cukup dan tepat.

Tabel 1. 1Data Akuntan Publik Tahun 2020

\begin{tabular}{|l|c|}
\hline \multicolumn{1}{|c|}{ Status } & Jumlah (Orang) \\
\hline Sanksi Pembekuan Izin & 13 \\
\hline Akuntan Publik Cuti (berstatus aktif) & 40 \\
\hline Akuntan Publik Non-Aktif & 249 \\
\hline Akuntan Publik Aktif & 1369 \\
\hline Jumlah & 1671 \\
\hline
\end{tabular}

Sumber:www.pppk.kemenkeu.go.id

Berdasarkan tabel diatas menunjukkan bahwa jumlah Akuntan Publik yang terdaftar (pemegang izin praktek) sebanyak 1671 orang, dan Akuntan Publik yang masih aktif sebanyak 1369, beberapa sisanya banyak yang tidak aktiif, cuti, maupun terkena sanksi pembekuan izin oleh Pusat Pembinaan Profesi Keuangan.

Tabel 1. 2Data Kantor Akuntan Publik Tahun 2020

\begin{tabular}{|l|c|}
\hline \multicolumn{1}{|c|}{ Status } & Jumlah \\
\hline Cabang KAP & 165 \\
\hline KAP bekerja sama dengan KAPA/OAA & 70 \\
\hline KAP Non-Aktif & 817 \\
\hline KAP Aktif & 473 \\
\hline
\end{tabular}

Sumber: www.pppk.kemenkeu.go.id 
Jurnal Akuntansi Manajerial

ISSN (E): 2502-6704

Vol. 5, No. 2 Juli - Desember 2020: 1-17
Dipublikasikan oleh Fakultas Ekonomi dan Bisnis

Universitas 17Agustus 1945 Jakarta

http://journal.uta45jakarta.ac.id/index.php/JAM

Berdasarkan data di atas jumlah KAP yang terdaftar di Pusat Pembinaan Profesi Keuangan adalah sebanyak 1290, diantaranya KAP yang masih aktif sebanyak 473 sedangkan KAP yang nonaktif sebanyak 817. Beberapa KAP yang memiliki cabang (memperoleh izin) sebanyak 165 dan KAP yang bekerja sama dengan Kantor Akuntan Publik Asing (KAPA) atau Organisasi Audit Asing (OAA) sebanyak 70. Mengamati gambaran umum mengenai jumlah Akuntan Publik yang tidak terlalu signifikan, kita patut khawatir akan terjadinya kelangkaan sebuah profesi keuangan di Indonesia.

Kasus PT Asuransi Jiwasraya sedang dalam proses hukum di Kejaksaan Agunng RI. Proses klarifikasi sedang dilakukan dan publik pun menanti untuk mengetahui siapa yang disalahkan dalam sengkarut masalah ini. Dalam kasus ini dinilai adanya indikasi penggiringan opini bahwa yang paling bersalah dalam kasus Jiwasraya adalah akuntan publik yang melakukan audit laporan keuangan. Sebab akuntan publik seharusnya bisa mencium hal adahal yang tidak beres dalam keuangan Jiwasraya saat melakukan audit. Pada tahun 2012-2016, KAP yang ditunjuk adalah KAP Soejatna, Mulyana, dan Rekan. Sementara sejak 2010-2013 adalah KAP Hertanto, Sidik dan Rekan. Pada tahun 2014-2015 adalah KAP Djoko, Sidik dan Indra. Sehingga pada tahun 2016, Menteri Keuangan dan OJKmemutuskan untuk memanggil Kantor Akuntan Publik (KAP) The Big Four yaitu PricewaterhousCoopers ( $\mathrm{PwC}$ ). BPK sebelumnya juga mengungkapkan bahwa ada aksi window dressing atau istilahnya mempercantik saat Jiwasraya menyajikan laporan keuangan 2006, namun anehnya hal ini tidak tercium oleh otoritas terkait. PwC memberikan opini wajar tanpa pengecualian atas laporan konsolidasian PT Asuransi Jiwasraya (Persero) dan entitas anaknya pada tanggal 31 desember 2016.

Laba bersih Jiwasraya yang dimuat dalam laporan keungan yang telah diaudit dan ditandatangani oleh auditor PwC tanggal 15 Maret 2017 itu menunjukkan laba bersih tahun 2016 adalah sebesar Rp 1,7 triliun. Sementara itu laba bersih Jiwasraya menurut laporan keuangan auditan tahunan 2015 adalah Rp 1,06 triliun.Pada 10 oktober 2018, Jiwasraya mengumumkan tak mampu membayar klaim polis JS Saving Plan yang jatuh tempo sebesar Rp 802 miliar. Seminggu kemudian Rini Soemarno yang menjabat sebagai Menteri Negara BUMN melaporkan dugaan fraud atas pengelolaan investasi Jiwasraya. Audit BPK selama 2015-2016 menjadi rujukan. Dalam audit tersebut disebutkan investasi Jiwasraya dalam bentuk medium tern notes (MTN) PT Hanson International Tbk (MYRX) senilai Rp 680 miliar, berisiko gagal bayar. Berdasarkan laporan audit BPK, perusahaan dilakukan banyak melakukan investasi pada aset berisiko untuk mengejar imbal hasil tinggi, sehingga mengabaikan prinsip kehati-hatian. Pada 2018, sebesar 22,4\% atau Rp 5,7 triliun dari total aset finansial perusahaan ditempatkan pada saham, tetapi hanya 5\% yang ditempatkan pada saham LQ45. Lalu 59,1\% atau Rp 14,9 triliun ditempatkan pada reksadana, tetapi hanya $2 \%$ yang dikelola oleh top tier manajer investasi. Kondisi-kondisi tersebut menyebabkan kerugian hingga modal Jiwasraya minus. Negara diperkirakan mengalami kerugian hingga Rp 13,7 miliar. (www.beritasatu.com).

Pada penelitian kaliini peneliti mencoba menganalisis tiap variabel yang dinilai memiliki keterkaitan antara satu variabel dengan yang lainya dengan menjadi sebuah judul "Pengaruh Audit Fee dan Financial Distress Terhadap Auditor Switching Dengan Manajemen Laba Akrual Sebagai Variabel Intervening". Berdasarkan hasil uraian diatas peneliti ingin mengetahui dan menganalisis mengenai pengaruh audit fee dan financial distress terhadap auditor switching dengan manajemen laba akrual sebagai variabel mediasi pada perusahaan yang terdaftar di Bursa Efek Indonesia (BEI) pada sektor real estate dan property tahun 2014-2018. 
Jurnal Akuntansi Manajerial

ISSN (E): 2502-6704

Vol. 5, No. 2 Juli - Desember 2020: 1-17
Dipublikasikan oleh Fakultas Ekonomi dan Bisnis

Universitas 17Agustus 1945 Jakarta

http://journal.uta45jakarta.ac.id/index.php/JAM

\section{LANDASAN TEORI}

\section{Teori Agensi (Agency Theory)}

Grand Theory yang mendasari dalam penelitian ini adalah teori keagenan.Teori keagenan merupakan teori yang menjelaskan hubungan antara agent (manajemen) dan principal (pemilik). Teori keagenan pertama kali dicetuskan oleh Jensen \& Meckling(1976) bahwa teori keagenan ialah perjanjian antara satu atau lebih pihak yang disebut prinsipal dengan pihak lain yaitu agen yang diberi tugas untuk bertindak mengutamakan kepentingan prinsipal dan melibatkan pendelegasian beberapa wewenang dalam pengambilan keputusan. Masalah agensi timbul karena adanya konflik kepentingan dan asimetri informasi antara prinsipal dan agen. Konflik-konflik tersebut nantinya akan berpengaruh terhadap hal-hal yang dapat menyebabkan perusahaan melakukan auditor switching, karena agen berada pada posisi yang memiliki informasi lebih banyak tentang perusahaan dibandingkan dengan prinsipal. Berdasarkan teori keagenan pihak prinsipal mempekerjakan agen untuk melakukan tugas demi kepentingan prinsipal, termasuk dalam pendelegasian otoritas pengambilan keputusan. Prinsipal memiliki harapan bahwa agen akan menghasilkan return darri uang yang mereka investasikan. Di lain pihak, agen memiliki tanggung jawab sepenuhnya untuk mengelola perusahaan sesuai dengan keinginan prinsipal. Sebagai wujud dari akuntabilitas manajemen kepada pemilik, setiap periode manajemen memberikan laporan mengenai informasi perusahaan kepada pemiliknya.

Asimetri informasi (information asymmetry) ialah suatu kondisi di mana ada ketidakseimbangan perolehan informasi antara pihak manajemen sebagai penyedia informasi dengan pihak pemegang saham dan stakeholder pada umumnya sebagai pengguna informasi (user), adanya asimetri informasi memungkinkan adanya konflik yang terjadi antara principal dan agent untuk saling mencoba memanfatkan pihak lain untuk kepentingan sendiri (Lisa, 2012).

\section{Teori Signal (Signaling Theory)}

Teori ini digunakan untuk menjadi pemisah antara beberapa variabel. Middle teori yang digunakan dalam penelitian ini adalah teori signal. Menurut Brighanm (2011) teori signal adalah suatu tindakan yang diambil manajemen suatu perusahaan yang memberi petunjuk bagi investor tentang bagaimana manajemen memandang prospek perusahaan. Teori signal menjelaskan bahwa pemberian sinyal dilakukan oleh manajer untuk mengurangi asimetriinformasi.

Manajer memberikan informasi melalui laporan keuangan bahwa mereka menerapkan kebijakan akuntansi konservatisme yang menghasilkan laba yang berkualitas untuk mencegah perusahaan melakukan tindakan fraud karena manajer adalah pihak yang mempunyai informasi yang akurat mengenai nilai dan kondisi perusahaan yang tidak diketahui oleh pihak lain. Informasi yang lengkap, relevan, akurat dan tepat waktu diperlukan oleh para investor sebagai alat ukur untuk mengambil keputusan (Cipta Dian Istiana, 2016).

\section{PENGEMBANGAN HIPOTESIS}

\section{Pengaruh Audit Fee terhadap Manajemen Laba Akrual}

Penetapan audit fee tidak kalah penting didalam menerima penugasan, auditor tentu bekerja untuk memperoleh penghasilan yang memadai. Besaran fee audit yang akan diterima auditor diduga berpengaruh terhadap kualitas audit. Oleh karena itu, penentuan fee audit perlu disepakati antara klien dengan auditor sesuai dengan risiko penugasannya agar tidak terjadi perang tarif yang dapat 
Jurnal Akuntansi Manajerial

ISSN (E): 2502-6704

Vol. 5, No. 2 Juli - Desember 2020: 1-17
Dipublikasikan oleh Fakultas Ekonomi dan Bisnis

Universitas 17Agustus 1945 Jakarta

http://journal.uta45jakarta.ac.id/index.php/JAM

merusak kredibilitas akuntan publik. Sejumlah fee audit yang dibayarkan kepada auditor atas jasa audit yang diberikannya, memungkinkan terjadinya penurunan profesionalisme auditor. Imam (2009) menunjukkan hasil bahwa audit fee berpengaruh negatif terhadap manajemen laba. Penurunan fee dapat mempengaruhi sikap independensi auditor dalam mendeteksi manajemen laba yang dilakukan oleh manajer.

H1: Audit feeberpengaruh positif terhadap manajemen laba akrual

\section{Pengaruh Financial Distress terhadap Manajemen Laba Akrual}

Dalam lingkup bisnis financial distress merupakan dimana perusahaan mencakup periode awal penurunan kinerja hingga ke titik terendah kemudian tahap pemulihan apabila perusahaan bisa memperbaiki kinerjanya. Apabila kinerja semakin buruk, maka kemungkinan besar perusahaan akan menghadapi kebangkrutan. Perusahaan yang mengalami penurunan asset biasanya akan menahan dividen dalam angka yang signifikan guna memperbaiki operasional dan kelangsungan hidup perusahaan. Penelitian yang dilakukan oleh M.Fauzal Aidi(2020) mengungkapkan bahwa financial distress memiliki pengaruh positif dan signifikan terhadap manajemen laba. Dalam hal ini perusahaan yang mengalami kesulitan keuangan akan mempengaruhi manajemen laba yang dibuat oleh seorang manajer dalam pelaporan hasil kinerjanya.

H2: Financial distress berpengaruh positif terhadap manajemen laba akrual

\section{Pengaruh Audit Fee terhadap Auditor Switching}

Fee atas jasa audit yang dilakukan nominalnya tidak ditentukan, hanya peusahaan dan auditor saja yang mengetahui. Karena tidak adanya peraturan yang menjelaskan besarnya fee audit atas jasa yang dilakukannya. Schwartz \& Menon(1985)menyatakan bahwa hal yang mendrong perusahaan melakukan auditor switching dapat disebabkan oleh audit fee yang relative tinggi sehingga tidak terjadi kesepakatan antara dua pihak mengenai besaran audit feetersebut yang menyebabkan perusahaan melakukan auditor switching.Fee auditor yang tinggi akan membuat perusahaan melakukan auditor switching secara sukarela (voluntary) yaitu akan berpindah kepada KAP yang menawarkan fee auditor yang lebih rendah dan terjangkau oleh perusahaan. Akan tetapi fee auditor yang lebih rendah juga akan menimbulkan kurangnya kualitas audit dan tingkat independensi auditor (Putra, 2020). Karena jika semakin besar fee audit yang didapat maka kompleksitas dan risiko audit yang dilakukan akan semakin meningkat. Semakin besarnya fee audit yang diberikan perusahaan kepada auditor atau KAP, maka akan semakin besar pula tingkat keahlian dan risiko audit yang didapat. Hasil penelitian ini sejalan dengan teori menurut (Mulyadi, 2002) menyatakan besarnya fee audit tergantung pada risiko penugasan serta tingkat keahlian dalam menjalankan penugasan tersebut.

H3: Audit fee berpengaruh positif terhadap auditor switching

\section{Pengaruh Financial Distress terhadap Auditor Switching}

Financial distress merupakan suatu situasi ketika sebuah perusahaan tidak mampu memenuhi kewajibannya. Chen dan Chang (2005) mengungkapkan bahwa kemungkinan kesulitan keuangan yang lebih tinggi adalah positif terkait dengan perubahan auditor yang telah mencapai signifikansi statsistik. Harum (2017) menyatakan bahwa perusahaan yang sedang mengalami kesulitan keuangan akan cenderung mengalami kesulitan dalam membayar jasa auditnya. Penelitian yang dilakukan oleh Farida (2019) menunjukkan bahwa financial distress berpengaruh terhadap auditor switching. Hal ini 
Jurnal Akuntansi Manajerial ISSN (E): 2502-6704

Vol. 5, No. 2 Juli - Desember 2020: 1-17
Dipublikasikan oleh Fakultas Ekonomi dan Bisnis

Universitas 17Agustus 1945 Jakarta

http://journal.uta45jakarta.ac.id/index.php/JAM

sejalan dengan penelitian yang dilakukan oleh Aini (2019) dan Yudha (2019) mengungkapan hasil yang sama yaitu financial distress berpengaruh terhadap auditor switching.

$\mathrm{H} 4$ : Financial distress berpengaruh terhadap auditor switching

\section{Pengaruh Manajemen Laba Akrual terhadap Auditor Switching}

Manajemen laba didefinisikan sebagai upaya manajer perusahaan untuk mengintervensi atau mempengaruhi informasi-informasi dalam laporan keuangan dengan tujuan untuk mengelabui stakeholder yang ingin mengetahui kinerja dan kondisi perusahaan. Lin \& Liu(2010) menyatakan bahwa manajemen laba merupakan faktor yang signifikan yang mempengaruhi auditor switching.

H5 : Manajemen laba akrual berpengaruh terhadap auditor switching

\section{Pengaruh Manajemen Laba Akrual terhadap Audit Fee dan Auditor Switching}

Dalam suatu lingkup bisnis terdapat manajemen laba merupakan proses untuk mengambil langkah tertentu yang disengaja dalam batas-batas prinsip akuntansi berterima umum untuk menghasilkan tingkat yang diinginkan dari laba yang dilaporkan. Dalam penelitian Williams (1988) menyatakan bahwa manajemen laba mempengaruhi adanya auditor switching. Dalam mengelola laba yang dilaporkan dan pengurangan biaya audit, perusahaan cenderung akan menggantikan auditor. Dimana perusahaan biasanya menginginkan biaya audit yang lebih rendah. Audit fee merupakan biaya yang diperoleh atas jasa yang dilakukan. Semakin tinggi fee yang dibayarkan semakin besar pula resiko yang akan didapat. Menurut penelitian Bayu Pradhana \& Dharma Suputra, (2015) menyatakan bahwa audit fee berpengaruh signikan terhadap auditor switching.

H6 : Manajemen laba akrual memediasi pengaruh audit fee terhadap auditor switching

\section{Pengaruh Manajemen Laba Akrual terhadap Financial Distress dan Auditor Switching}

Manajemen laba bisa dikatakan sebagai fleksibilitas akuntansi untuk menyetarafkan diri dengan inovasi bisnis. Akan tetapi perilaku manajer untuk bermain-main dengan komponen akrual yang discretionary untuk menentukan besar kecilnya laba, sebab standar akuntansi memang menyediakan berbagai alternatif metode dan prosedur yang bisa dimanfaatkan. Financial distress ialah dimana perusahaan sudah tidak sanggup membayar hutangnya sesuai jatuh tempo dan aset yang dimiliki tidak cukup untuk membayar hutangnya. Penelitian Naili \& Primasari(2020) Dalam hal ini perusahaan cenderung akan menggantikan auditor yang kualitasnya lebih baik dengan tujuan agar dapat menarik para investor terhadap laporan keuangan yang disajikannya.

H7 : Manajemen laba akrual memediasi pengaruh financial distress terhadap auditor switching

\section{METODOLOGI PENELITIAN}

\section{Populasi dan Sampel}

Menurut Ridwan (2016) populasi merupakan objek atau subjek yang berada pada suatu wilayah dan memenuhi syarat-syarat tertentu berkaitan dengan masalah penelitian. Sedangkan sampel adalah bagian dari populasi yang mempunyai ciri-ciri atau keadaan tertentu yang akan diteliti, karena tidak semua data dan informasi akan diproses dan tidak semua orang atau benda akan diteliti melainkan cukup dengan menggunakan sampel yang mewakilinya. Populasi dalam penelitian ini adalah 63 perusahaan real estate \& property yang terdaftar di BEI selama periode 2014-2018. Teknik pengambilan sampel yang digunakan dalam penelitian ini adalah purposive sampling method. 
Jurnal Akuntansi Manajerial

ISSN (E): 2502-6704

Vol. 5, No. 2 Juli - Desember 2020: 1-17
Dipublikasikan oleh Fakultas Ekonomi dan Bisnis

Universitas 17Agustus 1945 Jakarta

http://journal.uta45jakarta.ac.id/index.php/JAM

Metode ini melakukan pemilihan sampel denganberbagai pertimbangan/kriteria untuk tujuan tertentu. Adapun kriteria-kriteria dalam pemilihan sampel adalah sebagai berikut:

a) Perusahaan Real Estate \& Property yang sudah terdaftar di Bursa Efek Indonesia (BEI) tahun 2014-2018.

b) Perusahaan Real Estate \& Property yang menyertakan laporan keuangan dan laporan auditor independen selama periode 2014-2018.

c) Perusahaan yang menyajikan infomasi lengkap berupa nama KAP, opini audit, nama CEO, total asset, total hutang, dan total ekuitas.

\section{Jenis dan Sumber Data}

Sumber data dalam penelitian ini adalah sumber data sekunder dalam bentuk data keuangan dan ratio pada perusahaan real estate \& property yang terdaftar di Bursa Efek Indonesia tahun 2014-2018. Menurut Riduwan (2016:37) data sekunder adalah data yang dihimpun melalui tangan kedua.

\section{Operasional Variabel}

Tabel 3.1 Operasional Variabel

\begin{tabular}{|c|c|}
\hline Variabel Penelitian & Indikator Pengukuran \\
\hline $\begin{array}{l}\text { Audit Fee }\left(\mathbf{x}_{1}\right) \text {, sebagai besarnya biaya atas } \\
\text { hasil dari jasa audit tergantung resiko } \\
\text { penugasan, tingkat keahlian jasa, dan } \\
\text { ukuran KAP tersebut. Sukrisno } \\
\text { Agoes(2012) }\end{array}$ & Audit Fee $=\frac{\text { Audit Fee }}{\text { Laba Bersih }} \times 100 \%$ \\
\hline $\begin{array}{l}\text { Financial Distress }\left(\mathbf{x}_{2}\right) \text {, sebagai suatu } \\
\text { situasi ketika sebuah perusahaan tidak } \\
\text { mampu memenuhi kewajibannya. } \\
\text { Hilangnya sumber keuangan (keadaan } \\
\text { keuangan memburuk) dan sumber daya } \\
\text { manusia mungkin merupakan awal dari } \\
\text { terjadinya kebangkrutan. (Karlina et al., } \\
\text { 2018) }\end{array}$ & DER $=\frac{\text { Total Kewajiban }}{\text { Total Aset }} X 100 \%$ \\
\hline $\begin{array}{l}\text { Manajemen Laba Akrual (z), suatu } \\
\text { tindakan manajer yang menaikkan } \\
\text { (menurunkan) laba yang dilaporkan dari } \\
\text { unit yang menjadi tanggung jawabnya yang } \\
\text { tidak mempunyai hubungan dengan } \\
\text { kenaikan atau penurunan profitabilitas } \\
\text { perusahaan dalam jangka panjang. Fischer } \\
\text { \& Rozenzwig (1995) }\end{array}$ & 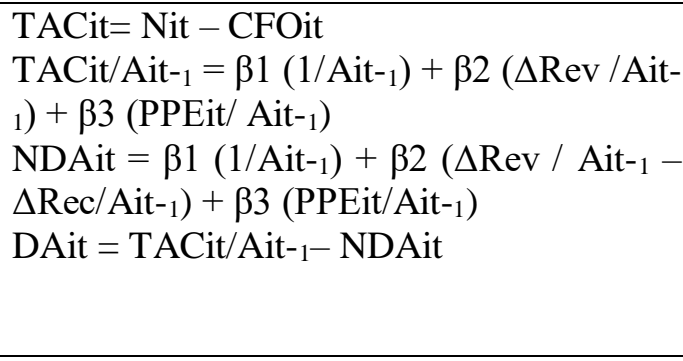 \\
\hline $\begin{array}{l}\text { Auditor Switching (y), perpindahan auditor } \\
\text { yang dilakukan oleh perusahaan audit } \\
\text { rekanan atas kewajiban yang harus } \\
\text { dilakukan sebagaimana diatur dalam } \\
\text { Keputusan Menteri Keuangan Nomor } \\
\text { 359/KMK.06/2003 Pasal 2. Sanulika (2018) }\end{array}$ & $\begin{array}{l}\text { Variabel ini menggunakan variabel } \\
\text { dummy, dimana bagi perusahaan yang } \\
\text { melakukan auditor switching diberi nilai } 1 \\
\text { sedangkan bagi perusahaan yang tidak } \\
\text { melakukan praktik auditor switching diberi } \\
\text { nilai } 0 \text {. }\end{array}$ \\
\hline
\end{tabular}


Jurnal Akuntansi Manajerial

ISSN (E): 2502-6704

Vol. 5, No. 2 Juli - Desember 2020: 1-17
Dipublikasikan oleh Fakultas Ekonomi dan Bisnis

Universitas 17Agustus 1945 Jakarta

http://journal.uta45jakarta.ac.id/index.php/JAM

\section{Metode Analisis Data}

Dalam penelitian ini teknik analisis data yang digunakan yaitu analisis kuantitatif. Analisis kuantitatif dilakukan dengan cara menganalisis suatupermasalahan yang diwujudkan dengan kuantitatif. Dalam penelitian ini, analisiskuantitatif dilakukan dengan cara mengkuantifikasi data-data penelitian sehinggamenghasilkan informasi yang dibutuhkan dalam analisis. Alat analisis yang digunakan dalam penelitian ini adalah analisis linear dan analisis regresi logistik (logistic regression). Alasan penggunaan alat analisis dengan menggunakan dua pengujian regresi adalah karena variabel dependen yang bersifat dikotomi (melakukan auditor switching atau tidak melakukan auditor switching) dan bariabel intervening merupakan rasio. Dalam pengujian menggunakan regresi logistik ssumsi normal distribution tidak dapat dipenuhi karena variabel bebasmerupakan campuran antara variabel kontinyu (metrik) dan kategorial (nonmetrik). Dalam hal ini analisis regresi logistik dapat dianalisis dengan regresi logistik (logistic regression)karena tidak perlu asumsi normalitas data pada variabel bebasnya. Artinya penjelasannya tidak harus memiliki distribusi normal, linear, maupun memilikivarian yang sama dalam setiap kelompok, sehingga tahapan dalam setiap pengujiandengan menggunakan uji regresi linear dan logistik (logistic regression) dapat dijelaskansebagai berikut (Ghozali, 2011):

\section{ANALISIS DAN PEMBAHASAN}

\section{Statistik Deskriptif}

Statistik deskriptif adalah statistik yang digunakan untuk menganalisa data dengan cara mendeskripsikan atau menggambarkan data yang telah terkumpul sebagaimana adanya tanpa bermaksud membuat kesimpulan yang berlaku untuk umum atau generalisasi (Sugiyono, 2008:206)

Tabel 4. 1 Hasil Uji Analisis Deskriptif

\begin{tabular}{|c|c|c|c|c|c|}
\hline Variabel & Obs & Mean & Std. Dev. & Min & Max \\
\hline SWITCH & 95 & 0,1157895 & 0,3216698 & 0 & 1 \\
\hline FEE & 95 & 0.0894016 & 0.085806 & 0.0199309 & 0.4838856 \\
\hline DER & 95 & 0,8390121 & 0,6313912 & 0,0356873 & 3,700959 \\
\hline DAC & 95 & 0,2290208 & 0,1493619 & 0,0150008 & 0,8198157 \\
\hline \multicolumn{6}{|c|}{$\begin{array}{l}\text { Keterangan: } \\
\text { Signifikansi ditingkat } 5 \% \text { atau } 0,05 \\
\text { Auditor Switchingyang diukur menggunakan variabel dummy (jika melakukan pergantian auditor diberi nilai 1, jika tidak } \\
\text { diberi nilai 0. } \\
\text { Audit Feediukur menggunakan } \\
\text { Financial Distressdiukur menggunakan Debt Equity Ratio (DER) yaitu (jumlah liabilittas / jumlah ekuitas) x } 100 \% \text {. } \\
\text { Manajemen Laba Akrual yang diukur menggunakan (DACit = (TACit/Ait-1) - NDAit }\end{array}$} \\
\hline
\end{tabular}

Dari tabel diatas dapat diketahui bahwa jumlah data yang digunakan dalam penelitian ini adalah sebanyak 95 sampel. Berdasarkan Hasil analisis dengan menggunakan statistik deskriptif terhadap auditor switching (SWITCH) menunjukkan nilai minimun sebesar 0, nilai maksimum sebesar 1 dengan Std Dev sebesar 0.3216698. hal ini menunjukkan bahwa rata-rata perusahaan real estate \& properti di BEI memiliki nilai auditor switching sebesar 0,1157895. 
Jurnal Akuntansi Manajerial

ISSN (E): 2502-6704

Vol. 5, No. 2 Juli - Desember 2020: 1-17
Dipublikasikan oleh Fakultas Ekonomi dan Bisnis

Universitas 17Agustus 1945 Jakarta http://journal.uta45jakarta.ac.id/index.php/JAM

\section{Pengujian Hipotesis Linear Berganda}

\begin{tabular}{|c|c|c|c|c|}
\hline DAC & Coef. & Std. Err & $\mathbf{Z}$ & $\mathbf{P}>\mathbf{Z}$ \\
\hline FEE & -.4332982 & .1892406 & 2.29 & .022 \\
\hline DER & -.0021567 & .0287661 & 0.07 & .940 \\
\hline Cons & .2695678 & .0377616 & 7.14 & .000 \\
\hline \multicolumn{4}{|l|}{ Number of obs } & 95 \\
\hline \multicolumn{4}{|l|}{ Number of groups } & 19 \\
\hline \multicolumn{4}{|l|}{ Wald chi2(3) } & 5.29 \\
\hline \multicolumn{4}{|l|}{ Prob > chi2 } & .0711 \\
\hline \multicolumn{4}{|l|}{ sigma_u } & .09392378 \\
\hline \multicolumn{4}{|l|}{ sigma_e } & .12005225 \\
\hline rho & .37968464 & \multicolumn{3}{|c|}{ (fraction of variance due to $u \_i$ ) } \\
\hline
\end{tabular}

\section{Tabel 4. 2 Hasil Pengujian Hipotesis}

Sumber: Data sekunder yang diolah, 2020

Berdasarkan hasil pengujian analisis berganda diatas, menunjukan bahwa secara simultan seluruh variabel nilai Prob 0,0711>0,05, maka dapat disimpulkan bahwa secara simultan audit fee, dan financial distress tidak mempengaruhi manajemen laba akrual. Pengujian parsial untuk masingmasing variabel dilakukan dengan melihat Prob > chi2 dari masing-masing variabel audit fee, financial distress, management change terhadap manajemen laba akrual, dengan hasil sebagai berikut:

a) Variabel FEE menunjukkan nilai Prob > chi2 sebesar 0,022 lebih kecil dari $\alpha=5 \%$ sehingga $\mathrm{H} 0$ ditolak dan Ha diterima, maka dengan tingkat keyakinan 95\% audit fee berpengaruh secara signifikan terhadap manajemen laba akrual.

b) Variabel DER menunjukkan nilai Prob > chi2 sebesar 0,940 lebih besar dari $\alpha=5 \%$ sehingga H0 diterima dan Ha ditolak, maka dengan tingkat keyakinan 95\% financial distress tidak berpengaruh secara signifikan terhadap manajemen laba akrual.

\section{Uji Multikolinearitas}

Uji multikolonieritas bertujuan untuk menguji apakah model regresiditemukan adanya korelasi antar variabel bebas (independen). Model regresi yangbaik adalah regresi dengan tidak adanya gejala korelasi yang kuat di antaravariabel bebasnya.Jika nilai VIF $>10$ dapat di indikasikan terjadi multikolinearitas dan jika nilai VIF $<10$ dapat di indikasikan tidak terjadi multikolinearitas.

Tabel 4. 3 Hasil Uji Multikolinearitas

\begin{tabular}{|l|l|l|l|l|}
\hline & KD & SK & SM & KI \\
\hline SWITCH & 1.0000 & & & \\
\hline FEE & 0.1106 & 1.0000 & & \\
\hline DER & -0.0410 & 0.0050 & 1.0000 & \\
\hline DAC & 0.1092 & -0.1942 & -0.0106 & 1.0000 \\
\hline \multicolumn{5}{|c|}{ Sumber: Data sekunder yang diolah, 2020 } \\
\hline
\end{tabular}

Sumber: Data sekunder yang diolah, 2020

Pada hasil pengujian multikolinearitas yang disajikan pada tabel 4.11, indikasi adanya korelasi yang kuat antar variabel independen ditunjukan dengan angka korelasi yang melebihi 0,8 . Hasil uji multikolinearitas menunjukan bahwa tidak ada hasil korelasi antar variabel independen yang melebihi 0,8 sehingga dapat disimpulkan tidak terdapat masalah kolinearitas pada variabel-variabel independen dalam model. 
Jurnal Akuntansi Manajerial

ISSN (E): 2502-6704

Vol. 5, No. 2 Juli - Desember 2020: 1-17
Dipublikasikan oleh Fakultas Ekonomi dan Bisnis

Universitas 17Agustus 1945 Jakarta

http://journal.uta45jakarta.ac.id/index.php/JAM

\section{Menilai Keseluruhan Model (Overall Model Fit)}

Untuk menilai overall fit model terhadap data digunakan nilai -2 likelihood.Hipotesis yang diuji adalah sebagai berikut:

H0: model yang dihipotesiskan fit dengan data

HA: model yang dihipotesiskan tidak fit dengan data

Pengujian dilakukan dengan membandingkan nilai antara -2 LogLikelihood (-2LL) pada awal (Block Number $=0)$ dengan nilai -2 Log Likelihood(-2LL) pada akhir (Block Number $=1)$. Apabila terjadi penurunan nilai -2 LogLikelihood dari model awal (konstanta saja) ke model setelah variabel bebasdimasukkan, maka Ho diterima dan Ha ditolak, berarti model yang dihipotesiskanfit dengan data (Ghozali, 2011).

Tabel 4. 4 Hasil Uji Overall Model Fit

\begin{tabular}{|c|c|}
\hline \multicolumn{1}{|c|}{ Keterangan } & Nilai \\
\hline -2Log Likehood pada awal (blok number $=0$ ) & 68,105692 \\
\hline -2Log Likehood pada awal (blok number $=5$ ) & 65,631704 \\
\hline
\end{tabular}

Sumber: Data sekunder yang diolah, 2020

Dari Tabel 4.12 menunjukkan Nilai -2LL awal adalah sebesar68,105692.Setelah dimasukkan ketiga variabel independen, maka nilai -2LL akhirmengalami penurunan menjadi sebesar65,631704. Berdasarkan hasil tersebut, makaH0 diterima dan Ha ditolak, penurunan likelihood (-2LL) ini menunjukkan modelregresi yang lebih baik atau dengan kata lain model yang dihipotesiskan fit dengan data.

\section{Koefisien Determinasi (Nagelkerke R Square)}

Untuk mengetahui seberapa besar variabel audit fee, financial distress, dan manajemen laba akrual terhadap auditorswitching pada perusahaan real estate\& properti yang terdaftar di Bursa Efek Indonesia (BEI) selama periode 2014-2018 digunakan nilai Nagelkerke $R$ Square. Nagelkerke $R S q u a r e$ merupakan modifikasi dari Cox and Snell $R$ Square yang dapatdiintepretasikan seperti nilai $R$ Square pada regresi linier berganda (Ghozali,2011).

Tabel 4. 5 Hasil Uji Koefiseien Determinasi

\begin{tabular}{|c|c|}
\hline -2Log Likelihood & Nagelkerke R Square \\
\hline 65,379984 & 0.0400 \\
\hline
\end{tabular}

Sumber: Data sekunder yang diolah, 2020

Berdasarkan dari tabel 4.13 nilai Nagelkerke R Square sebesar 0,4877 yang berarti variabel dependen dapat dijelaskan oleh variabel independen sebesar 4\%, sedangkan sisanya sebesar 96\% dijelaskan oleh variabel-variabel lain diluar variabel penelitian.hal tersebut menunjulan bahwa secara bersama-sama variasi variabel bebas (audit fee, financial distress dan manajemen laba akrual) dapat menjelaskan variasi variabel auditor switching sebesar $4 \%$.

\section{Menguji Kelayakan Model}

Kelayakan model regresi dilakukan dengan pengujian Hosmer andLemeshow's Goodness of Fit Test untuk mengetahui apakah data empiris cocokatau sesuai dengan model (tidak ada perbedaan antara model dengan datasehingga model dapat dikatakan fit), melalui kriteria sebagai berikut:

a. Jika nilai signifikansi Hosmer and Lemeshow $=0,05$, artinya ada perbedaansignifikan antara model dengan nilai observasinya sehingga goodness fitmodel tidak baik karena model tidak dapat memperbaiki nilai observasinya.

b. Jika nilai signifikansi Hosmer and Lemeshow > 0,05, artinya model mampumemprediksi nilai observasinya atau dapat dikatakan model dapat diterimakarena fit dengan data observasinya (Ghozali, 2011). 
Jurnal Akuntansi Manajerial ISSN (E): 2502-6704

Vol. 5, No. 2 Juli - Desember 2020: 1-17
Dipublikasikan oleh Fakultas Ekonomi dan Bisnis Universitas 17Agustus 1945 Jakarta http://journal.uta45jakarta.ac.id/index.php/JAM

Tabel 4. 6 Hasil Uji Kelayakan Model Regresi

\begin{tabular}{|c|c|}
\hline Chi Square & Prob > Chi \\
\hline 13,58 & 0.6555 \\
\hline
\end{tabular}

Sumber: Data sekunder yang diolah, 2020

Tabel 4.14 menunjukan hasil pengujian hosmer and Lemeshow's Test. Berdasarkan tabel 4.14, dapat diketahui bahwa nilai signifikasi $0.6555>0,05$ yang berarti model mampu memprediksi nilai observasinya atau dapat dikatakan model dapat diterima karena fit dengan data observasinya.

\section{Analisis Model}

Tabel 4. 7 Hasil Pengujian Regresi Logistik

\begin{tabular}{|l|c|c|c|r|}
\hline SWITCH & Coef. & Std. Err & $\mathbf{Z}$ & P>z \\
\hline FEE & 4.082771 & 3.098211 & 1.32 & 0.188 \\
\hline DER & -.2536356 & .5914915 & -0.43 & 0.668 \\
\hline DAC & 2.605174 & 2.021984 & 1.29 & 0.198 \\
\hline Cons &.-2.878667 & .8814158 & -2.27 & 0.001 \\
\hline Number of obs & & 95 \\
\hline LR chi2 (3) & & 2.7 \\
\hline Prob > chi2 & 0.4359 \\
\hline Pseudo R2 & & 0.0400 \\
\hline
\end{tabular}

Sumber: Data sekunder yang diolah, 2020

Tabel 4.15 merupakan output dari hasil pengujian regresi logistik yang merupakan respon dari 3 variabel yaitu FEE, DER, dan DAC. Berdasarkan persamaan regresi logistik diatas diketahui bahwa nilaiconstant untuk persamaan regresi (a) adalah -2,878667. Hal ini dapat disimpulkanbahwa apabila nilai audit fee, financial distress, dan manajemen laba akrual bernilai 0, maka auditor switching akan mengalami kenaikan sebesar -2,878667, dengan nilai interpretasi hasil disajikan sebagaiberikut:

a) Variabel FEE menunjukkan koefisien regresi sebesar 4,082772 dengan tingkat signifikansi $(p)$ sebesar 0,188 lebih besar dari $\alpha=5 \%$.

b) Variabel DER menunjukkan koefisien regresi sebesar -0,2536356 dengan tingkat signifikansi (p) sebesar 0,668 lebih besar dari $\alpha=5 \%$.

c) Variabel DAC menunjukkan koefisien regresi sebesar 2,605174 dengan tingkat signifikansi (p) sebesar 0,001 lebih kecil dari $\alpha=5 \%$.

Hasil pengujian terhadap koefisien regresi menghasilkan model berikut ini:

SWITCH $=-2,878667+4,082772 F E E+-0,2536356 C E O+-2,605174 \mathrm{DAC}+e$

Pengujian Hipotesis Regresi Logistik

Tabel 4. 8 Hasil Pengujian Hipotesis Regresi Logistik Audit Fee, Financial Distress, dan Manajemen Laba Akrual terhadap Auditor Switching

\begin{tabular}{|l|c|c|c|r|}
\hline SWITCH & Coef. & Std. Err & $\mathbf{Z}$ & \multicolumn{1}{|c|}{ P>z } \\
\hline FEE & 4.082771 & 3.098211 & 1.32 & 0.188 \\
\hline DER & -.2536356 & .5914915 & -0.43 & 0.668 \\
\hline DAC & 2.605174 & 2.021984 & 1.29 & 0.198 \\
\hline Cons &.-2.878667 & .8814158 & -2.27 & 0.001 \\
\hline Number of obs & & 95 \\
\hline LR chi2 (3) & & 2.7 \\
\hline Prob > chi2 & & 0.4359 \\
\hline Pseudo R2 & & 0.0400 \\
\hline
\end{tabular}

Sumber: Data sekunder yang diolah, 2020 
Jurnal Akuntansi Manajerial

ISSN (E): 2502-6704

Vol. 5, No. 2 Juli - Desember 2020: 1-17
Dipublikasikan oleh Fakultas Ekonomi dan Bisnis

Universitas 17Agustus 1945 Jakarta

http://journal.uta45jakarta.ac.id/index.php/JAM

Berdasarkan hasil pengujian analisis berganda diatas, menunjukan bahwa secara simultan seluruh variabel nilai Prob 0,4359>0,05, maka dapat disimpulkan bahwa secara simultan audit fee, financial distress dan manajemen laba akrualtidak mempengaruhi auditor switching.

Pengujian parsial untuk masing-masing variabel dilakukan dengan melihat Prob > chi2 dari masing-masing variabel audit fee, financial distress, danmanajemen laba akrual terhadap auditor switching, dengan hasil sebagai berikut:

a) Variabel FEEmenunjukkan nilai Prob > chi2 sebesar 0,188 lebih besar dari $\alpha=5 \%$ sehingga H0 diterima dan Ha ditolak, maka dengan tingkat keyakinan 95\% audit fee tidak berpengaruh secara signifikan terhadap auditor switching.

b) Variabel DER menunjukkan nilai Prob > chi2 sebesar 0,668 lebih besar dari $\alpha=5 \%$ sehingga H0 diterima dan Ha ditolak, maka dengan tingkat keyakinan 95\% financial distress tidak berpengaruh secara signifikan terhadap auditor switching.

c) Variabel DAC menunjukkan nilai Prob > chi2 sebesar 0,001 lebih kecil dari $\alpha=5 \%$ sehingga H0 ditolak dan Ha diterima, maka dengan tingkat keyakinan 95\% manajemen laba akrual berpengaruh secara signifikan terhadap auditor switching.

Tabel 4. 9 Hasil Pengujian Hipotesis Regresi Logistik Audit Fee, Financial Distress, dan Manajemen Laba Akrual terhadap Auditor Switching

\begin{tabular}{|c|c|c|c|c|}
\hline DAC & Coef. & Std. Err & $\mathbf{Z}$ & $P>Z$ \\
\hline FEE & -.3379638 & .175185 & -1.93 & 0.054 \\
\hline DER & -.0022675 & -.0238076 & -0.10 & 0.924 \\
\hline Cons & .2611378 & .0294062 & 8.88 & 0.000 \\
\hline SWITCH & Coef. & Std. Err & $\mathbf{Z}$ & $\mathbf{P}>\mathbf{Z}$ \\
\hline DAC & .2351929 & .2196359 & 1.07 & 0.284 \\
\hline Cons & .0619254 & .0599589 & 1.03 & 0.302 \\
\hline \multicolumn{4}{|c|}{ Number of obs } & 95 \\
\hline \multicolumn{4}{|c|}{ Log Likelihood } & 30.571034 \\
\hline \multicolumn{4}{|l|}{ Chi2 (2) } & 1,91 \\
\hline \multicolumn{4}{|l|}{ Prob > chi 2} & 0.3850 \\
\hline
\end{tabular}

Sumber: Data sekunder yang diolah, 2020

\section{Gambar 4. 1 Path Analisys Audit Fee, Financial Distress, dan Manajemen Laba Akrual terhadap Auditor Switching}

Sumber: Data sekunder yang diolah, 2020

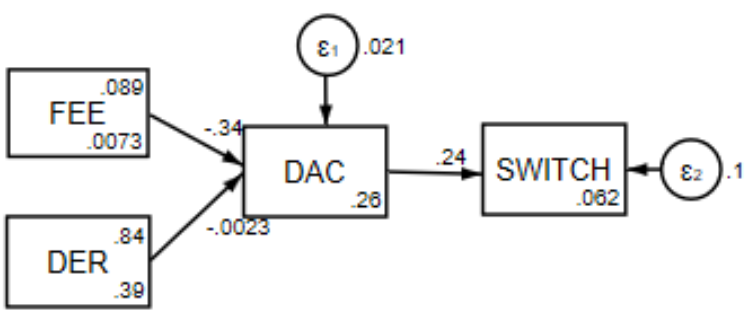

Pengujian hipotesis untuk variabel Auditor Fee dan Finansial Distress terhadap auditor switching yang dimediasi oleh manajemen laba akrual dilakukan dengan melihat Prob $>$ chi2 sebesar 0,3850 < 0,05 sehingga H0 diterima dan Ha ditolak, maka dengan tingkat keyakinan 95\% manajemen laba akrual tidak berhasil memediasi Auditor Fee dan Finansial Distress terhadap auditor switching. 
Jurnal Akuntansi Manajerial

ISSN (E): 2502-6704

Vol. 5, No. 2 Juli - Desember 2020: 1-17
Dipublikasikan oleh Fakultas Ekonomi dan Bisnis

Universitas 17Agustus 1945 Jakarta

http://journal.uta45jakarta.ac.id/index.php/JAM

\section{HASIL PENELITIAN}

1. Hasil Penelitian ini menunjukkan bahwa terdapat pengaruh pada audit fee terhadap manajemen laba akrual. Sehingga besar atau kecilnya fee yang diberikan memiliki hubungan besar terhadap praktek manajemen laba yang dilakukan oleh manajer. Penelitian ini sejalan dengan penelitian yang dilakukan oleh (Imam, 2009) menunjukkan bahwa audit fee berpengaruh signifikan terhadap manajemen laba. Berdasarkan hasil penelitian, maka dengan ini H1 di terima.

2. Hasil penelitian ini menunjukkan bahwa financial distress tidak berpengaruh terhadap manajemen laba akrual. Hal ini berarti bahwa perusahaan dalam keadaan bangkrut atau tidak, meereka akan tetap melakukan manajemen laba dan tindakan ini tidak dapat dideteksi oleh tata kelola perusahaan. Hasil penelitian ini sejalan dengan penelitian yang dilakukan oleh (Christina \& Alexander, 2019) menyatakan bahwa financial distress tidak berpengaruh terhadap manajemen laba akrual. Berdasarkan hasil penelitian, maka dengan ini $\mathrm{H} 2$ di tolak.

3. Hasil penelitian ini menunjukkan bahwa audit fee tidak berpengaruh terhadap auditor switching. Manajemen perusahaan cenderung memakai jasa KAP yang sudah memiliki reputasi tinggi hal itu sebagai pencitraan untuk perusahaan (Handini, 2017). Hasil penelitian ini sejalan dengan Handini (2017) dan Amalia (2015), yang menyatakan bahwa audit fee tidak berpengaruh terhadap auditor switching. Berdasarkan hasil penelitian, maka dengan ini H3 di tolak.

4. Hasil penelitian ini menunjukkan bahwa financial distress tidak berpengaruh terhadap auditor switching. Perpindahan KAP dapat menjadi beban tambahan bagi perusahaan. Selain itu independensi KAP juga menjadikan salah satu faktor yang menjadi salah satu alasan untuk tidak melakukan perpindahan KAP meskipun perusahaan dalam kondisi yang kurang baik (Handini, 2017). Hasil penelitian ini mendukung hasil penelitian sebelumnya yang dilakukan olehPradana dan Saputra (2015) dan Handini (2017), yang menyatakan bahwa financial distress tidak berpengaruh terhadap auditor switching. Berdasarkan hasil penelitian, maka dengan ini $\mathrm{H} 4$ ditolak.

5. Hasil penelitian ini menunjukkan bahwa manajemen laba akrual tidak berpengaruh terhadap auditor switching. Berganti manajemen cenderung akan mengubah kebijakan baru pula, termasuk bergantinya auditor. Karena manjemen yang baru akan memaksimalkan kinerja untuk mendapatkan prestasi yang baik sehingga sulit untuk memanipulasikan laba yang diperolehNur Azizah dan Kim Budiwinarto (2019). Hasil penelitian ini bertolak belakang dengan hasil penelitian Lin \& Liu(2010) menyatakan bahwa manajemen laba merupakan faktor yang signifikan yang mempengaruhi auditor switching. Berdasarkan hasil penelitian, maka dengan ini H5 di tolak.

6. Hasil penelitian ini menunjukkan bahwa manajemen laba akrual tidak dapa memediasi pengaruh audit fee terhadap auditor switching. KAP yang independen akan memberikan hasil audit yang mendasar pada materialitas dan menghindari tekanan dari klien dalam memberikan opininya, serta perusahaan tidak melakukan auditor switching, karena untuk menjaga kepercayaan pemegang saham dan kreditur hal ini disebabkan karena apabila perusahaan sering melakukan pergantian auditor akan menimbulkan anggapan yang negatif (Pradana dan Saputra, 2015). Hasil penelitian ini bertolak belakang dengan hasil penelitian Williams (1988) menyatakan bahwa manajemen laba mempengaruhi adanya auditor switching dan Bayu Pradhana \& Dharma Suputra, (2015) menyatakan bahwa audit fee berpengaruh signikan 
Jurnal Akuntansi Manajerial

ISSN (E): 2502-6704

Vol. 5, No. 2 Juli - Desember 2020: 1-17
Dipublikasikan oleh Fakultas Ekonomi dan Bisnis

Universitas 17Agustus 1945 Jakarta

http://journal.uta45jakarta.ac.id/index.php/JAM

terhadap auditor switching.Semakin tinggi fee yang dibayarkan semakin besar pula resiko yang akan didapat. Berdasarkan hasil penelitian, maka dengan ini H6 di tolak.

7. Hasil penelitian ini menunjukkan bahwa manajemen laba akrual tidak dapa memediasi pengaruh financial distress terhadap auditor switching. Hasil penelitian ini bertolak belakang dengan hasil penelitian Naili \& Primasari (2020) Dalam hal ini perusahaan cenderung akan menggantikan auditor yang kualitasnya lebih baik dengan tujuan agar dapat menarik para investor terhadap laporan keuangan yang disajikannya. Berdasarkan hasil penelitian, maka dengan ini $\mathrm{H} 7$ di tolak

\section{KESIMPULAN}

1. Audit Fee (FEE) pengujian dengan regresi linear berganda menunjukkan koefisien regresi negatif sebesar $-0,4332982$ dengan tingkat signifikansi $(p)$ sebesar 0,022 lebih besar dari $\alpha=5 \%(0,05)$. Maka audit feeberpengaruh terhadap manajemen laba akrual.

2. Financial Distress (DER) pengujian dengan regresi linear berganda menunjukkan nilai koefisien regresi negatif sebesar -0,0021567 dengan tingkat signifikansi $(p)$ sebesar 0,940 lebih besar dari $\alpha=5 \%(0,05)$. Maka financial distress tidak berpengaruh terhadap manajemen laba akrual.

3. Audit Fee (FEE) pengujian dengan regresi logistik menunjukkan nilai koefisien regresi positif sebesar 4.082772 dengantingkat signifikansi $(p)$ sebesar 0,188 lebih besar dari $\alpha=$ 5\% (0,05). Maka audit feetidak berpengaruh terhadap auditor switching.

4. Financial Distress (DER) pengujian dengan regresi logistik menunjukkan nilai koefisien regresi negatif sebesar $-0,2536356$ dengan tingkat signifikansi $(p)$ sebesar 0,668 lebih besar dari $\alpha=5 \%(0,05)$. Maka financial distresstidak berpengaruh terhadap auditor switching.

5. Manajemen Laba Akrual (DAC) pengujian dengan regresi logistik diperoleh nilai koefisien regresi positif sebesar 2.605174 dengan tingkat signifikansi $(p)$ sebesar 0,198 lebih besar dari $\alpha=5 \%(0,05)$. Maka manajemen laba akrualtidak berpengaruh terhadap auditor switching.

6. Audit Fee (FEE) dan Manajemen Laba Akrual (DAC) pengujian dengan regresi logistik diperoleh nilai Prob $>$ chi2 sebesar $0,3850<\alpha=5 \%(0,05)$. Maka manajemen laba akrualtidak berhasil memediasi pengaruh audit fee terhadap auditor switching

7. Financial Distress (DER) dan Manajemen Laba Akrual (DAC) pengujian dengan regresi logistik diperoleh nilai Prob > chi2 sebesar 0,3850< $\alpha=5 \%(0,05)$. Maka manajemen laba akrualtidak berhasil memediasi pengaruh financial distress terhadap auditor switching.

\section{DAFTAR PUSTAKA}

Ali, M., \& Hamid, A. (2008). Why Malaysian Second Board Companies Switch Auditors: Evidence of Bursa Malaysia. International Research Journal of Finance and Economics, 13(13).

Amrizal dan Amelia. (2016). Pengaruh Opini Audit, Ukuran Perusahaan, Dan Pergantian Manajemen Terhadap Auditor Switching Pada Perusahan Manufaktur Subsektor Makanan Dan Minuman. IJEA Indonesian Journal of Economics Application, 16(2), 214-243. http://ojs.itb-ad.ac.id/index.php/IJEA/article/view/224/165

Bayu Pradhana, M., \& Dharma Suputra, I. (2015). Pengaruh Audit Fee, Going Concern, Financial 
Jurnal Akuntansi Manajerial

ISSN (E): 2502-6704

Vol. 5, No. 2 Juli - Desember 2020: 1-17
Dipublikasikan oleh Fakultas Ekonomi dan Bisnis

Universitas 17Agustus 1945 Jakarta

http://journal.uta45jakarta.ac.id/index.php/JAM

Distress, Ukuran Perusahaan, Pergantian Manajemen Pada Pergantian Auditor. E-Jurnal Akuntansi, 11(3), 713-729.

Chadegani, A. A., Mohamed, Z. M., \& Jari, A. (2011). The Determinant Factors of Auditor Switch among Companies Listed on Tehran Stock Exchange. International Research Journal of Finance and Economics, 80(80), 159-168.

Christina, S., \& Alexander, N. (2019). The Effect of Corporate Governance and Corporate Diversification on Earnings Management. Modern Economics, 14(1), 7-12. https://doi.org/10.31521/modecon.v14(2019)-01

Cipta Dian Istiana. (2016). Pengaruh Financial Distress, Rentabilitas, Pertumbuhan Perusahaan Dan Opini Audit Terhadap Auditor Switching. Penelitiann Akuntansi FEB, UMP, 1-10.

De Fond, M. L. (1992). The Association Between Changes in Client Firm Agency Costs and Auditor Switching. A Journal of Practice \& Theory, 11(1). https://doi.org/10.1109/ICSSSM.2017.7996193

Diandika, K. H., \& Badera, I. D. N. (2017). Financial Distress Sebagai Pemoderasi Pengaruh Fee Audit pada Auditor Switching. E-Jurnal Akuntansi Universitas Udayana, 18(1), 246-275.

Ghozali, I. (2016). Aplikasi Analisis Multivariate dengan Program IBM SPSS 23. (Edisi 8). Semarang: Badan Penerbit Universitas Diponegoro.

Giri, E. F. (2010). Pengaruh Tenur Kantor Akuntan Publik (KAP) Dan Reputasi KAP Terhadap Kualitas Audit: Kasus Rotasi Wajib Auditor di Indonesia. Simposium Nasional Akuntansi XIII, 1-26.

Imam, H. (2009). Pengaruh Kualitas Audit Dan Auditor Switching Terhadap Manajemen Laba. Simposium National Accounting, 2(5), 45-67.

Jensen, M. C., \& Meckling, W. H. (1976). Theory of The Firm: Mangerial Behavior, Agency Cost and Ownnership Structure. Journal of Financial Economics, 3, 305-360. https://doi.org/10.1177/0018726718812602

Karlina, Lindrianasari, \& Gamayuni, R. R. (2018). Determinant analysis of audit report lag in regional governments in Indonesia. International Journal of Scientific and Technology Research, 7(4), 105-110.

Kusuma, H. A. (2019). Faktor-faktor yang Mempengaruhi Perusahaan Melakukan Auditor Switching Pada Perusahaan Manufaktur di BEI Periode 2014-2017. Jurnal FEB Akuntansi, UII, 4(1), 75-84. https://doi.org/.1037//0033-2909.I26.1.78

Lin, Z. J., \& Liu, M. (2010). The determinants of auditor switching from the perspective of corporate governance in China. Advances in Accounting, 26(1), 117-127. https://doi.org/10.1016/j.adiac.2010.03.001

Lisa, O. (2012). Asimetri Informasi dan Manajemen Laba: Suatu Tinjauan Dalam Hubungan Keagenan. WIGA-Jurnal Penelitian Ilmu Ekonomi, 2(1), 42-49.

M.Fauzal Aidi. (2020). Pengaruh Konservatisme Akuntansi, Leverage, Risiko Litigasi, Financial Distress, dan Pengungkapan CSR terhadap Manajemen Laba Akrual Pada Perusahaan Jasa Transportasi Yang Terdaftar di BEI Periode 2015-2019.

Maemunah, S., \& Nofryanti. (2019). Pergantian Manajemen Memoderasi Pengaruh Ukuran Kap Dan Audit Tenure Terhadap Auditor Switching (Studi Empiris Pada Perusahaan Keuangan Sub Sektor Perbankan Yang Terdaftar Di Bursa Efek Indonesia Tahun 2013-2017). Jurnal Renaissance, 4(01), 533-540. http://www.ejournal-academia.org/index.php/renaissance 
Jurnal Akuntansi Manajerial

ISSN (E): 2502-6704

Vol. 5, No. 2 Juli - Desember 2020: 1-17
Dipublikasikan oleh Fakultas Ekonomi dan Bisnis

Universitas 17Agustus 1945 Jakarta

http://journal.uta45jakarta.ac.id/index.php/JAM

Maharani, D. P. (2015). PENGARUH KUALITAS AUDITOR EKSTERNAL DAN KOMITE AUDIT TERHADAP TAX AVOIDANCE (Studi Empiris terhadap Perusahaan yang Tercatat di Indeks Kompas 100 Bursa Efek Indonesia Tahun 2010-2013). In Skripsi Ilmiah Universitas Diponegoro.

Nagy, A. L. (2005). Mandatory audit firm turnover, financial reporting quality, and client bargaining power: The case of arthur andersen. Accounting Horizons, 19(2), 51-68. https://doi.org/10.2308/acch.2005.19.2.51

Naili, T., \& Primasari, N. H. (2020). Audit Delay, Ukuran Kantor Akuntan Publik, Financial Distres, Opini Audit, Dan Ukuran Perusahaan Klien Terhadap Auditor Switching. Jurnal Ilmiah Akuntansi Universitas Pamulang, 8(1), 63-74.

Najwa, V. A., \& Syofyan, E. (2020). Pengaruh Management Change, Ukuran Perusahaan Klien, dan Audit Fee terhadap Auditor Switching. Jurnal Eksplorasi Akuntansi, 2(2), 2726-2739.

Putra, R. R. (2020). PENGARUH EMPLOYEE MORALITY DAN LEADERSHIP STYLE TERHADAP ACCOUNTING FRAUD TENDENCIES YANG. Journal Uta 45 Jakarta, 5(1), $1-15$.

Rahman, F. (2019). Pengaruh Ukuran Kantor Akuntan Publik dan Financial Distress terhadap Auditor Switching. Jurnal Keuangan Dan Bisnis, 5(2), 148-162.

Safriliana, R., Subroto, B., Subekti, I., \& Fuad Rahman, A. (2018). An Overview on Contracting Theory and Agency Theory: Determinants of Voluntary Public Accounting Firms Switching. KnE Social Sciences, 3(10), 10-21. https://doi.org/10.18502/kss.v3i10.3381

Sanulika, A. (2018). Pengaruh Opini Audit, Peringkat Kap, Ukuran Perusahaan Dan Profitabilitas Terhadap Nilai Perusahaan Dengan Auditor Switching Sebagai Variabel Mediasi. Scientific Journal of Reflection: Economic, Accounting, Management and Bussines, 1(4), 11-20. https://doi.org/10.5281/zenodo.1436982

Schwartz, K. B., \& Menon, K. (1985). Switches by Failing Firms. The Accounting Review, 60(2), $248-261$.

Sukrisno Agoes. (2012). Auditing Petunjuk Praktis Pemeriksaan Akuntan Oleh Akuntan Publik. Salemba Empat, Jakarta. https://doi.org/10.1142/s242478632050005x

Taufiqur, M. A. (2019). Pengaruh Opini Audit, Financial Distress , Pertumbuhan Perusahaan, Ukuran KAP dan Pergantian Manajemen Terhadap Auditor Switching.

Wandeca, J. S. (2012). Analisis Pengaruh Pergantian Chief Executive Officer (CEO) Terhadap Praktek Manajemen Laba (Studi Pada Perusahaan BUMN dan Non BUMN di Bursa Efek Indonesia). Universitas Lampung. http://fe-akuntansi.unila.ac.id

Wibowo, C. F., \& Majidah, D. (2019). Auditor Switching: Faktor Auditor dan Auditee. EProceeding of Management, 6(2), 2994.

Wibowo dan Rahmawati. (2019). Reveal Voluntary Auditor Switching Determinants in Indonesia: Evidence from Financial Services Sector. Jurnal Dinamika Akuntansi, 11(1), 1-14. https://doi.org/http://dx.doi.org/10.15294/jda.v11i1.18042

Widarti. (2017). Fee Audit Sebagai Mediasi Pengaruh Kualitas Audit Terhadap Manajemen Laba (Analisis Jalur). Jurnal Akuntansi, 5(1), 57. https://doi.org/10.24964/ja.v5i1.251

Widnyani, N. L. E. D., \& RM, K. M. (2018). Pengaruh Opini Audit, Audit Fee, Reputasi KAP dan Ukuran Perusahaan Klien Terhadap Auditor Switching. E-Jurnal Akuntansi, 23, 1119. https://doi.org/10.24843/EJA.2018.v23.i02.p12 
Jurnal Akuntansi Manajerial

ISSN (E): 2502-6704

Vol. 5, No. 2 Juli - Desember 2020: 1-17
Dipublikasikan oleh Fakultas Ekonomi dan Bisnis

Universitas 17Agustus 1945 Jakarta

http://journal.uta45jakarta.ac.id/index.php/JAM

Wijaya, E., \& Rasmini, N. (2015). Pengaruh Audit Fee, Opini Going Concern, Financial Distress, Ukuran Perusahaan, Ukuran Kap Pada Pergantian Auditor. E-Jurnal Akuntansi, 11(3), 940966.

Williams, D. D. (1988). The Potential Determinants of Auditor Change. Journal of Business Finance \& Accounting, 15(2), 243-261. https://doi.org/10.1111/j.1468-5957.1988.tb00133.x

Wulandari, E., Cahyono, D., \& Martiana, N. (2018). Reputasi Auditor sebagai Pemoderasi Pengaruh Financial Distress dan Audit Fee pada Auditor Switching. E-Jurnal Akuntansi, 8(2), 58. https://doi.org/10.24843/eja.2018.v24.i01.p03

Yudha, C. K., \& Saputra, K. A. K. (2019). Pengaruh Opini Going Concern, Pergantian Manajemen, Kesulitan Keuangan, Dan Reputasi Auditor Pada Auditor Switching. Jurnal Riset Akuntansi Dan Keuangan Dewantara, 2(2), 82-95. https://doi.org/10.21538/0134-4889-2017-23-4-257264

Yunawati, S., \& Zulkarnain, Z. (2019). The Determinant Factors of Auditor Switch (Empirical studies to Companies listed on Indonesian Stock Exchange). International Journal on Advanced Science, Education, and Religion, 2(2), 9-16. https://doi.org/10.33648/ijoaser.v2i2.31 